\title{
Constructions of collective Muslim identity by advocates of Muslim schools in Britain
}

\author{
Claire Tinker and Andrew Smart
}

\begin{abstract}
This paper considers how and why collective Muslim identity is expressed and mobilized by advocates of Muslim schools in Britain. This relates to broader questions about the conceptualization, construction and meanings of Muslim identities, and the problem of essentialism that can arise when reporting identity claims that emphasize intra-group unity. Analysis of data from interviews with stakeholders in the debate about Muslim schools in Britain revealed advocates commonly regarded separate schooling as a protective measure against threats and/or attacks to Muslim identity. It is argued that interviewees invoked collective Muslim identity in ways that drew attention to common knowledge, values and practice, and/or shared life experiences relating to denigrated or discordant social identities. The commonalities expressed by respondents are interpreted as evidence of a convergence of identities and interests in particular social conditions, and are not claimed to be essential characteristics of collective Muslim identity.
\end{abstract}

\section{Keywords}

Muslim Schools, Collective Identity, Muslim, Claims-making, Multiculturalism, Education.

Collective Muslim identity is expressed and mobilized in group claims-making. This raises questions about the conceptualization and construction of collective Muslim identity (e.g. Modood 1998; Sayyid 2000), and the social conditions in which identities and interests converge (Hempel 2004). In this paper, these questions are considered in the context of debates about Muslim schools in Britain, using an analysis of qualitative interviews with stakeholders. It is revealed that advocates for Muslim schools commonly perceived Muslim identity to be under threat and/or attack, and considered separate schools as an appropriate means of defence. In expressing these arguments, two constructions of collective Muslim identity were apparent: 1) knowledge, values and practice, and/or 2) life experiences relating to denigrated or discordant social identities. These findings are discussed to reflect upon the formations and meanings of collective Muslim identity in the context of claims for Muslim schools. It will be argued that the expression or mobilization of identifications that emphasize intragroup unity is not evidence of essential group characteristics, but rather the convergence of identities and interests in particular social conditions.

\section{Background}

\section{Muslim identity}

Expositions of Muslim identity grapple with a tension between commonalities and diversities. On the one hand, it appears self-evident that all Muslims share 
some thing(s); the thing(s) that enable them to identify as Muslims (or allow other people to label them as such). On the other hand, there is unarguable diversity within the group 'Muslims'; not only national, ethnic, cultural, linguistic, political and sectarian variation, but also cross-cutting differences relating to class, gender, age/generation, migration, sexuality, disability, etc. The dualism of homogeneity and heterogeneity is not, of course, solely a problem when conceptualizing collective Muslim identity, but nevertheless it is prominent in scholarship on 'Muslims in the West'. Indeed, many authors adopt a position in which they reveal or defend the existence of heterogeneity (e.g. Modood 2007), and communicate a clear message: all Muslims are not the same. The prominence and tenor of this message can, at least in part, be explained by the intellectual impact of the 'anti-essentialist critique' (Modood 1998) and an antiracist undertone that accompanies concerns about prejudice and discrimination against Muslims.

Muslim identity can be analysed as a form of religious identity (Peek 2005). In his discussion of British Muslims, however, Meer (2008, p. 66) claims that 'rather than being scripturally informed, we can view Muslim identity as a quasi-ethnic sociological formation'. He justifies this conceptualization due to the blurred boundary between religion and ethnicity in relation to minority group experiences and political mobilizations. Moreover, it also emphasizes the intersection between Muslim identity as self-assigned and externally ascribed. Modood (2007, p. 134) identifies that the salient dimensions of identity for Muslims in Britain include: 'a sense of family', 'community membership and heritage', 'simple precepts about self, compassion, justice and the afterlife' and 'collective political advancement'. He notes, nevertheless, that in the current British context Muslims may often be positioned (or position themselves) as having an identity marked by 'difference' (p. 109).

A sociological lens focuses attention onto the political, social and economic processes and contexts involved in the creation and construction of identities (e.g. Schwedler 2001). In contemporary Britain, the politics of Muslim identity appear to be in flux. Modood argues that there is ongoing debate about 'what it is to be a Muslim' and a 'proliferation of Muslim organizations' each displaying and promoting 'a particular Muslim identity' (2007, p.140). For example, Kahani-Hopkins and Hopkins (2002, p. 294) describe the different ways that two Muslim political organizations invoke the concept of $d a$ ' wah - 'the injunction to invite people to Islam' (p. 288).

If more individualized identity constructions are considered, however, this fluidity appears to be the norm. Dwyer (1999, 2000), following Hall (1992), conceptualizes identity as 'contextual and relational positionings' (1999: 6), and views identity 'as a process that is always in progress' (2000: 475). Her analysis of young British South-Asian Muslim women attends to their multiple and intersecting identities, the contingent nature of 'difference', and how individuals subvert, resist and rework dominant meanings in their identity constructions. Hopkins (2007, p. 61) reveals considerable variation in the 'strength, nature and meaning' of individuals' affiliations to Muslim identity. This may be contingent on circumstance; for example, Ahmad and Venetia (2010) report that the sense of 'otherness' felt by some Muslims was heightened by political tensions. 
An author-created final version of article published in "Ethnic and Racial Studies", 2012, 35(4): 643-663. [copyright

Taylor \& Francis], available online at: http://dx.doi.org/10.1080/01419870.2011.577899.

\section{Muslim claims-making}

Muslims (individually and as a group) have become increasingly socially visible. The protests associated with The Satanic Verses in the 1980s marked the rise in a politicized Muslim identity (Modood 1992). By the end of the 1990s the Runnymede Trust (1997) was reporting discrimination against Muslims, and it was being argued that: 'the Muslim community has become increasingly a symbol of identification and collective action, particularly around issues of separate schools, religious education and religious discrimination.' (Alexander 1998, p. 441) The terrorist atrocities which followed the millennium cast a very different light on these nascent socio-political engagements; Muslims became perceived less as 'victims of social inequality' and more as 'potential aggressors'. Indeed, studies of British press coverage show that Muslims have been increasingly visible and often portrayed negatively (Poole 2002; Meer, 2006).

During this same time period, analysis of survey data suggested that many Muslims were prioritizing religious identity over other identifications (Modood et al. 1997). In addition, qualitative research provided evidence of situations in which Muslim identities were given primacy over other aspects of identity (see Modood 2007, p108-9). Of course, evidence of prioritization does not preclude the salience of other identities. As noted above, other social differentiations and contextual factors influence the expression of Muslim identities, including 'the dominant narratives of national identity' (Dwyer 2000, p.476). Indeed, in the context of debates about primacy and allegiance, it is the construction and potential salience of the compound identity 'British Muslim' that has come to the fore (Modood 2007).

Muslim identities have been mobilized for collective action (Statham 1999). As Statham et al. (2005, p. 439) note, however, various overlapping (and potentially competing) categories of collective identity are evident in group demands: 'The same migrant group may mobilize as 'Pakistanis', 'Asians'..., 'Muslims', 'British Muslims' or as 'ethnic minorities'. Statham et al.'s (2005) analysis of British newspaper coverage nevertheless showed that two thirds of demands were based on religious forms of identification, and of these the majority (61.4\%) were from groups identifying themselves as Muslim or Islamic. This evidence of a pattern of group claims-making is somewhat tempered by the aforementioned studies of press coverage. It does, however, demonstrate that collective Muslim identity is not only a focus for mobilization, but also it is part of a media narrative in which Muslims are sometimes presented as a group with common needs.

\section{Muslim schools}

Meer (2007, p. 55) argues that mobilizations for Muslim schools can be understood as 'an addition to - or continuation of - a historical settlement between earlier religious minorities, the established church and the state'. The contemporary existence of faith schools reflects the significant historical role of religious organizations in the development of the British education system. This predominantly involved the Protestant and Catholic churches (Chadwick 2001), although Jewish schools also have a heritage spanning four centuries (Miller 2001). Faith schools exist either 'independently' or within the state sector (where 
public funding has attendant policy and practice requirements). In Britain there are over 7000 faith schools in the state sector, although very few of these are non-Christian (in England this includes eleven Muslim schools) (Bolton and Gillie 2009). In addition, there are 140 independent Muslim schools in England and two in Wales. ${ }^{1}$ The Muslim Council of Britain (2007) estimates that there are over 400,000 school-aged Muslim children in Britain, and that only approximately $4 \%$ of these attend an independent school.

There is a broad spectrum of Muslim schools. Pupil numbers range from 5 to over 1800, and while some larger schools are purpose-built, many smaller schools operate in homes, offices or above mosques (Parker-Jenkins et al. 2005). The eleven state-funded Muslim schools are required to employ fully qualified teachers and follow the National Curriculum for England. Those in the independent sector (like all independent schools) need not follow these requirements, but nevertheless some choose to (Tinker 2009) while others claim they have insufficient resources to do so (Walford 2001).

Muslims schools are a relatively recent addition to the educational landscape; the first independent Muslim school opened in 1979 (Dooley 1991), and the first to enter the state sector was in 1998. This extension of state support to Muslim schools was mired by dispute and controversy. The first Muslim school admitted into the state sector had endured multiple rejections during a fifteen year campaign (Parker-Jenkins 2002), and it was not alone in experiencing opposition from central government (McLoughlin 1998). Consecutive Labour governments from 1997 promoted policies to increase the number of Christian and minority faith schools (Jackson 2003). Nevertheless, the idea of state-funded Muslim schools has continued to generate unease and debate.

Objections to initial applications for state support centred on resources and local necessity, and arguments about segregation in the context of multicultural education policies. It has been argued, however, that resistance ran much deeper. McLoughlin (1998, p. 451) claims that underlying perceptions of 'Islam and Muslim schools as necessarily 'separatist' and 'fundamentalist', meant that Christian schools did not face similar objections. Dwyer (1993, p. 149) similarly argued that the Muslim schools were subject to public and political distrust in ways that their Jewish and Catholic counterparts were not, because they were 'seen to offer a particular threat to the hegemonic culture'. Substantial differences in socio-historical context complicate direct comparisons between faith schools. Nevertheless, even since the shift to an ostensibly supportive policy environment, particular concerns about Muslim schools have persisted in relation to social cohesion, extremism and gender roles (Meer 2007). There is a continuing perception that Muslim schools are culturally 'out of place' or hazardous.

A key justification for Muslim schools (including in the state-sector) is the need for equality in an educational system which includes other faith schools. In addition, arguments have been made about the rights, choices or needs of parents, children and/or 'the Muslim community' (Hewer 2001; Parker-Jenkins 2002; Jackson 2003; Tinker 2006, 2009; Meer 2007; McCreery et al. 2007). These include: having educational institutions that are organized and run in ways that reflect religious (and/or cultural) values and practices (including gendered practices); communicating or inculcating particular religious and cultural knowledge, practices or values (which are viewed as marginalized if not wholly 
absent in the curricula of mainstream schools); enabling children to avoid the prejudice and discrimination that is perceived to occur in mainstream schooling and which is argued to undermine their self-confidence and self-identity; and, improving children's attainment. The rationale of protecting or supporting Muslim identity is highly prominent in these accounts. The promotion of Muslim identity (as an end in itself, rather than as an outcome of a principle of justice or an instrumental desire to enhance educational outcomes) is, however, controversial. Secular interest groups, and some politicians, journalists and academics, vehemently argue that religious identities should not be promoted by state-sanctioned education.

Heterogeneity in the construction and expression of Muslim identities must be recognized. Arguably, however, this marginalizes questions about the coherence and stability of collective Muslim identity. This paper explores how collective Muslim identity is constructed and expressed in the contentious arena of claims for Muslims schools. It seeks to examine what it is about collective Muslim identity that is most stable or most commonly attested to; and what might be the dominant formations and meanings in collective Muslim identity in this context.

\section{Methodology}

The findings reported in this paper originate from research (undertaken by CT) examining the debate about the state-funding of Muslim schools (Tinker 2006, 2009). A qualitative research design was favoured to enable an in-depth consideration of the outlooks of research participants on this potentially controversial topic (Mason 1996).

A purposive sampling technique ensured that participants with relevant views and experiences were recruited (Ritchie et al. 2003). Thirty-six interviews were organized with representatives from four stakeholder groups: political parties; interest groups; head teachers; and parents of Muslim school-children. Individuals within the four groups were selected in different ways. Documentary and on-line searches were used to identify representatives from four political parties and eleven interest groups (eight of which were 'Muslim interest groups', ranging from those focussed on education, through those with a general remit to serve the needs of Muslims, to those with overtly political aims). Head teachers of four independent Muslim schools were identified through contact with the Association of Muslim Schools, while eleven head teachers of state-maintained schools with a high proportion of Muslim pupils were identified through Local Education Authorities. Twelve parents were identified using a 'snowball' sample, following recommendations from head teachers or other parents.

Semi-structured interviews focused the data collection on key issues, but allowed respondents' some freedom to direct the discussion (Kvale 1996). Interview 'guides' varied between stakeholder groups, but common topics included the state-funding of faith schools in general and Muslim schools in particular. Interviews were conducted between July 2003 and March 2004 (by CT), each lasting approximately one hour. Interviews usually took place in the respondents' home or workplace, and were conducted in English.

Interviews were transcribed in full and imported into NVivo data analysis software package. CT constructed a list of codes from preliminary interviews, and applied these to subsequent data, expanding and compressing the coding 
frame as necessary. A 'thematic analysis' (Gomm 2004, p. 189) was developed, and the findings reported here comprise four themes relating to the justifications for Muslim schools that involved ideas about Muslim identity.

The research was conducted in accordance with the British Sociological Association (2002) statement on ethical practice. With so few state-funded Muslim schools in Britain, and a limited number of stakeholder organizations, there was a risk that some respondents may be identifiable. This limit on confidentiality was discussed with relevant interviewees, and it was agreed that quotations would be anonymized and related descriptors would aim to limit identifiability.

Certain restrictions in the study can be noted. The issue of 'interviewer effect' in this research is discussed in detail elsewhere (Tinker and Armstrong 2008). Many respondents (25/36) were Muslim and the interviewer is not, and in this respect, it is open to question whether the commonly recounted narratives of threat and/ or attack against Muslim identity would have been similarly generated in an interview with 'matched' religious affiliations. Conducting the interviews in English may have affected the potential pool of interviewees, and the possibilities of exploring deeper thoughts and feelings with respondents who spoke English as an additional language. Qualitative research rarely aims to have statistical generalizablility (Mason 1996). Thus, while the findings reported here chart the range of concerns expressed by this sample of respondents, questions about the representativeness of these opinions (among others who comprise the stakeholder group but were not in this sample) would require further research of a different design.

\section{Findings}

The overarching theme that emerged from the data analysis was a perception that Muslim identity was under threat and/or attack, and that separate Muslim schools were an appropriate means of protection or defence. Four sub-themes are presented below; these represent the range of ways in which ideas about identity were used by respondents to support the case for Muslim schools.

\section{The curriculum}

A concern most commonly aired by representatives of 'Muslim interest groups' was that Muslim identity may be confused, lost or denigrated because of the content of the curriculum in mainstream schools, both what was included and what was omitted. There were three perceived shortfalls in the curriculum: that it might contravene religious teaching, lack information about Islam or lack information about the achievements of Muslims.

A representative of an interest group that promotes Islam and serves the needs of Muslims argued that aspects of the curriculum, such as sex education and evolutionary theory, might contravene Islam:

Children spend about 7 or 8 hours at school, and they're taught all the wrong things. By wrong things I mean they are against the religion. They are teaching about Darwinist theory, about this family planning, sex and other things. [...] So when they come back after school it's a very hard job to clear those cobwebs in their minds. 
An author-created final version of article published in "Ethnic and Racial Studies", 2012, 35(4): 643-663. [copyright

Taylor \& Francis], available online at: http://dx.doi.org/10.1080/01419870.2011.577899.

This view reveals a fear that children's religious identity or affiliation may be confused if they are 'taught all the wrong things'; and it implies such contradictions would be avoided if children attended Muslim schools.

A lack of religious knowledge was also a concern for the above-quoted respondent. Here, he invoked the views of parents to support his opinion that Muslim schools best serve the interests of Muslims:

[...] for the parents, it is important that their children are getting religious education for longer. Which is necessary, because if you look at those other boys who go to those [non-Muslim] schools, ask them about their religion, 'I don't know, I don't know'. So, what they will be in their practical lives? Will they be Muslim, will they be Christian, will they be Jews, or nothing? Most of them will be nothing.

This viewpoint, that religious instruction is a necessary part of education, appears to be rooted in a fear that a lack of knowledge of Islam may result in a child losing their Muslim identity and becoming 'nothing'.

It was the systematic under-representation of the experiences, contributions and perspectives of non-European individuals and groups that most concerned a respondent at an interest group that campaigns and lobbies on behalf of 'the Muslim community':

$[\ldots]$ the national curriculum $[\ldots]$ is very Eurocentric. I think this has to change, to take into account the contribution other cultures and civilizations made to our civilization. [...] In these faith schools this young person will be told of the contribution their faith, their culture, their civilization has made to the wider civilization. They are not simply useless people.

This view, which connects self-confidence and collective identity, reveals a fear of a denigrated identity if Muslim pupils view themselves as part of a group of 'useless people'. The respondent contrasts this with opportunities afforded by faith schools which would purportedly reflect more positively 'their faith, their culture, their civilization'.

\section{Secular or Western values}

A second theme that emerged from the data analysis, most commonly expressed by head teachers of independent Muslim schools, related to the values, morals and behaviours inculcated by schools. Typically, the concern was that collective Muslim identity may be lost or undermined because aspects of secular or Western values are different and threaten 'good' 'Islamic' morals and behaviour.

One head teacher of an independent Muslim school invoked the views of parents (and then Muslims generally) when he argued that aspects of identity differ between Muslims and 'secularized people'.

When they see most secularized people, for example they see the dress code of the average British child, it sends a warning signal, it's not dressed according to the Sharia. When they see the drinking, it's not 
An author-created final version of article published in "Ethnic and Racial Studies", 2012, 35(4): 643-663. [copyright

Taylor \& Francis], available online at: http://dx.doi.org/10.1080/01419870.2011.577899.

according to Sharia. All these factors build a particular picture, a particular identity in the minds of Muslims. And they see the Muslim identity as distinctly different from the one that they see upon the street or on the television.

Other interviewees, such as this head teacher of a different independent Muslim school, viewed these allegedly secular values as threatening:

We see nothing to stop this tide of secular values becoming more into the fore. It scares us to be quite frank with you. And these are the ways that we try to safeguard ourselves, having Islamic schools, etcetera.

The views of these respondents suggest a perceived contrast between Islamic and secular values, and position Muslim schools as a means safeguarding collective identity.

It was also repeatedly claimed that pupils in mainstream state schools exhibit anti-social behaviour (with specific references to underage drinking, drug-taking, swearing and vandalism), and this was contrasted with the behaviour instilled by Muslim schools. For example, the head teacher of a third independent Muslim school argued that the school aimed to:

[...] bring the children up in an Islamic environment, and equip the children with Islamic manner and behaviour. Islamic manner and behaviour tells the children to be kind to the neighbours, to encourage them not to mess around, not to throw your banana skin in the street, or smoke cigarettes.

Similarly, a representative of an interest group that politically promotes the establishment of an Islamic state argued the role of Muslim schools was to:

$[\ldots]$ nurture the Islamic personality first and foremost. What that means essentially is a person's thoughts, his inclinations, that these are in line with Islam. [...] To give it a practical slant [...], this would mean that a Muslim would not put his parents in an old people's home because he would understand that his obligation is to look after his parents [...]

It is notable that the examples of 'Islamic manner and behaviours' or 'the Islamic personality' claimed by these respondents are actions or attitudes that many nonMuslims would also consider 'good'. These viewpoints suggest that Muslim schools were viewed as a way of instilling collective identity rooted in 'good' morals and behaviour, but they also imply a perception on the part of these respondents that Islam has a monopoly on these or that non-Muslims are immoral and/or badly-behaved.

A particular expression of the concern about values and the loss of identity related to gender. The head teacher quoted at the start of this sub-section reported that he struggles to convince some parents to allow their daughters to go to co-educational institutions after leaving his school:

$[\ldots]$ in a sense they are afraid that if they allow their girls to go on into mixed education schools or colleges that they'll lose their own identity, 
An author-created final version of article published in "Ethnic and Racial Studies", 2012, 35(4): 643-663. [copyright

Taylor \& Francis], available online at: http://dx.doi.org/10.1080/01419870.2011.577899.

become embroiled in things which are not Islamic. [...] They feel that the girls should not really be educated in [non-Muslim] schools because they'll be lost to Western society and so forth.

While this viewpoint is evidence of a perceived gender-specific identity threat from being 'embroiled in things which are not Islamic', the notion of loss is also striking; not only a loss of 'their own identity', but also that they will be 'lost to Western society'.

\section{Prejudice and discrimination}

Concern over prejudice and discrimination were widespread among the sample, but most commonly expressed by parents and head teachers. Characteristically, the fear was that Muslims were under attack and afforded little protection, and that this created risks to children's self-esteem or self-confidence.

The fear that Muslim children experience prejudice was commonly rooted in experience. For example, the parent of child who attended a mainstream state school claimed that her son's religious views had been unfairly criticized by both fellow pupils and teachers:

$[\ldots]$ the teacher would be putting him down, you know, 'you're not supposed to believe that and you're not supposed to say this'. [...] Not that he believed in any of the terrorists or anything like that, it's just the religion itself, that's what people were picking on. [...] They said it's wrong, and he will say 'you can't tell me that my religion is wrong'. He says 'anyway we don't believe in killing', because they said 'your religion is all about killing'.

Such perceptions, of attacks on belief, underpinned some parents' desire for defensive or protective measures.

This parent therefore sent her child to an independent Muslim school after having negative experiences in a mainstream state school:

I mean my youngest child when he was little he went to the state school he used to wear little hats. [...] Every day the boys in the playground would take his hat and put it on the roof, and the annoying thing was that I would get a complaint from the school that the caretaker had to keep on getting up. I said 'look you've got to respect the fact that he is wearing that, [...] you have got to educate other children not to keep throwing it on the top, not to keep telling me not to make him wear it, that's not fair'.

In this respondent's opinion, not only was her child subjected to discrimination because he expressed a Muslim identity in his clothing, but also the school offered no protection and subsequently blamed the problem on her.

It is in the context of such experiences that one head teacher argued that state-funded Muslim schools, such as his, were necessary to create: 'a sense of self-esteem and self-confidence in the children'. Indeed, he argued that restoring self-confidence to young Muslims was essential not only to ensure 'they will be able to participate fully and positively in the world outside', but also because those who lacked it were at risk of radicalization: 
An author-created final version of article published in "Ethnic and Racial Studies", 2012, 35(4): 643-663. [copyright

Taylor \& Francis], available online at: http://dx.doi.org/10.1080/01419870.2011.577899.

Without that self-confidence, our experience and observations and analysis is that they are very prey to a sort of identity crisis, $[\ldots]$ and then they possibly seek out some sort of strong, perhaps fundamentalist or extremist position which gives them a strong sense of identity.

For this respondent, having Muslim schools offered denigrated Muslim children a route out of an 'identity crisis' that alternatively risked losing them to the 'strong sense of identity' offered by fundamentalism or extremism. Indeed, he argued in particular that active support of Muslim school in the state sector was the best way to encourage the development of a secure British Muslim identity.

\section{Discordant identities}

A fourth theme that emerged from the data analysis, most commonly expressed by parents and head teachers, related to the potential for discord between sources of identity. In summary, some respondents viewed plural identities as a cause of unhappiness, confusion or conflict, and Muslim schools as source of a stable and coherent identity.

One fear was that Muslim pupils attending schools where there are few other Muslim children would result in them not 'fitting in'. For example, a parent of children at an independent Muslim school recalled his childhood 'identity crisis', the attendant feelings of isolation and how this influenced his decision about his children's education:

I didn't really know who I was [...]. At one time I thought well I'm English, I'm not Muslim I'm English, and I wanted to be as much English as I could, more English than the English, and I wanted to kind of pretend I had nothing else. And then I [...] swung the other way, I am Muslim and my dad is from Egypt although I've only been to Egypt a couple of times but I tried to, you know... But then I realized eventually that I am actually a bit of both. [...] It took me a long time to sort that out, and I feel that part of the reason was because I didn't have [...] anyone that I could identify with, I didn't have any guidance on the matter, I was kind of alone [...]. I just didn't want that for my children, I wanted my children to feel a strong sense of identity, that they belonged, that they were Muslim and they could be proud to be Muslim and there were other Muslims in this country and they felt happy about that. But at the same time, you know, I wanted them to have a good education and feel that this is their country and feel proud of their country as well.

This respondent believed that he could help to protect his children from isolation by sending them to a school that offered 'a strong sense of identity', which appeared to mean an identity that emphasized the collective: belonging, affiliation, pride in being part of a group and knowledge of the existence of 'other Muslims'. A potential conflict over a dual identity, nevertheless, remains evident in his juxtaposition of a Muslim identity to pride and belonging to 'their country'. 
An author-created final version of article published in "Ethnic and Racial Studies", 2012, 35(4): 643-663. [copyright

Taylor \& Francis], available online at: http://dx.doi.org/10.1080/01419870.2011.577899.

Another source of identity conflict was potential differences in expectations and behaviours at home and school. One head teacher of a statefunded Muslim school argued:

There is the possibility that children will grow up being very mixed up. They have one way of being at home and another way of being at school and that can cause problems.

The differences in the 'way of being' remained vague in this respondent's account (it is surmised that the source of differences were aspects of belief and behaviour reported above, which are further evident in the extract which follows below). Nevertheless there is concern that these variations impact on identity, with a risk of children being 'mixed up' if the differences are great.

A representative of an interest group that politically promotes the establishment of an Islamic state argued that 'the role of an Islamic school is to complement the role of a parent in educating children'. This view was echoed by a parent whose child attended an independent Muslim school, who suggested that conflict was avoided as the school reinforced parental messages:

Things like when we teach them eating manners and things like that. [...] I would say eat with your right hand, say 'bismillah' which means in the name of Allah. I, as a parent, would do that and that would be reinforced if they went to an Islamic school from a young age [because] the teacher would say 'can we all say our prayers together', 'can you make sure that you go and wash your hands and that you're all eating with the right hand'.

This solution to a perceived home-school conflict portrays an idealized harmony between parental and institutional viewpoints, but nevertheless it demonstrates an underlying concern with difference in religious (and cultural) beliefs and practice and posits 'an Islamic school' as a means to a coherent Muslim identity.

\section{Discussion}

Earlier in the paper questions were raised about collective Muslim identity (its common formations and attendant meanings) and the construction of claims for Muslim schools. Advocates of Muslim schools interviewed in this study commonly expressed a perception that Muslims were under threat and/or attack. This was sometimes infused by meanings that revealed fears about loss of identity, or even the loss of individuals from the group. Muslim identity was often seen as being challenged, denigrated and undermined by Western or secular ideas, values and behaviours. Threats came from perceived (overt and institutionalized) anti-Muslim prejudice, and from everyday 'non-Islamic' values and behaviours. As such, fears particularly focused on 'external' threats, relating to assimilation into Western, secular society, or from the identity-crises that might arise from majority/minority relations of power. Less frequently, fears extended to 'internal' threats - the loss of 'moderate' Muslims to 'radical' or 'extreme' Islam. In this threatening social context, Muslim schools offered various means of defence (that were differently emphasized by stakeholder groups). In sum, schools could instil or reinforce knowledge about Islam and 
related practices or modes of behaviour, and/or they could protect Muslim pupils from anti-Muslim prejudice (or extremism) and offer them a sense of worth. It is thus suggested that two constructions of collective Muslim identity were invoked in the context of advocacy for Muslim schools. The first related to knowledge, values and practices expressed in relation to religion but which sometimes blurred into ethnicity. The second centred on life experiences relating to denigrated or discordant social identities.

\section{Essentializing collective identity}

The respondents' arguments for Muslim schools draw on and reproduce ideas about collective Muslim identity. This evidence can be explained using the concept of 'strategic essentialism' (Spivak 1987), whereby those identifying with a particular group promote an idea of intra-group unity in order to further what they consider to be their, or the groups', interests. Employing this concept as an analytical tool, however, can leave the analyst open to an accusation that they are unfairly representing organizations or individuals by implying that an idea of group unity is being used instrumentally. Such an accusation is a particular concern for this study, as slyness and inscrutability are common Orientalist stereotypes (Said 1978) and the Runnymede Trust (1997) argues that portrayals of Islam as an instrumentalist political ideology (and subsequent representations of Muslims as manipulative and insincere) can be manifestations of Islamophobia. To clarify, it is not suggested that that respondents' in this study were disingenuous when they invoked ideas about collective Muslim identity, and it is worth re-iterating that such ideas were largely mobilized defensively, in social circumstances that respondents perceived as threatening.

The data reported above, however, also revealed an example of essentializing perpetrated by those who perceive themselves as resisting discrimination, which raises difficult questions (Thompson 2008). Negatively judgmental group stereotypes of immoral Western or secular 'others' were expressed by a few respondents as they marked out their identity in relative or oppositional terms. Bauman (1989, p. 64) discusses the 'antagonism generated by the human practices of identity-seeking and boundary-drawing', and for Jenkins (2008, p. 48) this boundary work is a 'ubiquitous feature of human sociability'. Modood (2008) argues that essentializing that excludes groups, or casts them as inferior, is different from that which is used to resist such activities. Such a division, however, is difficult to sustain. A claim for Muslims schools underpinned by negative stereotypes of non-Muslims is a claim based on stereotypes, regardless of whether the aim is to protect Muslim pupils against prejudice and discrimination. To the extent that strategic essentialism is an ideological activity, the distorted or misleading portrayals of 'other' groups or individuals that occur under its rubric could be considered ethnocentric, or even racist. ${ }^{2}$ Whether such outlooks are commonly generated, encouraged or legitimated by strategic essentialism is a question for further research.

\section{Avoiding essentialism}

Reporting these expressions of collective identity raises critical questions about the extent to which such findings essentialize, homogenize and/or reify the group under discussion. Recent sociological debates about multiculturalism have 
addressed such questions, and while the protagonists commonly reject conceptualizations of groups as static or homogenous, they offer different ideas about the relationship between individuals and groups. Meer and Modood (2009, p. 4) distinguish between formulations of multiculturalism that 'invalidate 'group' identities' and those that are 'inclusive of 'groupings', Three theoretical positions - that range from weak to strong in their conceptions of groups - are outlined below. They are used to explain different aspects of the expression and mobilization of collective Muslim identity in the data, while avoiding the risk of portraying these as essential group characteristics.

Meer and Modood (2009, p. 15) claim that Paul Gilroy's After Empire advocates 'multiculturalism without groups'. Gilroy (2004) champions the potential of convivial, cosmopolitan 'multiculture' against continuing racism and 'the endless narrative of immigration as invasion' (p. 166). With respect to group identity, Gilroy argues that ' $[\mathrm{t}]$ he radical openness that brings conviviality alive makes a nonsense of closed, fixed, and reified identity and turns attention toward the always-unpredictable mechanisms of identification' (2004, p. xi). This stance draws the analytical focus toward the processes and contexts of identifications (and away from the 'content' of collective identities). Hempel (2004) contends that explanations of 'ethnic identifications' need to examine the conditions under which identities and interests converge. In this study, the convergence of identities and interests was evident in respondents support for Muslim schools based on defensive narratives about threats to, and protection of, Muslim identity. The conditions for such expressions include ${ }^{3}$ : the minority status of the religion and its adherents (in terms of religious affiliation and often in terms of ethnicity); Britain's dominant secular (post-Christian) culture; prominent global and national political contexts; and, perceptions and experiences of prejudice and discrimination. They also, however, include a dominant socio-political context that promotes discourses of rights, equality and choice (including in relation to education), and where demands for equitable and 'culturally-sensitive' service provisions are commonplace. Other conditions relate to the responsibilities and concerns of parents and head teachers, and the organizational agendas of interest groups (and of schools). Gilroy's injunction to attend to the mechanisms of identification is thus analytically useful for the present study as it emphasizes the socio-political processes and contexts framing respondents' expressions of collective Muslim identity.

An analytical position in which groups are more prominent is offered by Anne Phillips in Multiculturalism without Culture. Phillips aims to 'address inequalities between cultural groups' $(2007$, p. 8), but opposes 'forms of multiculturalism that cede power and authority to cultural groups' as intra-group disagreement is masked when representatives become the 'definitive voice of 'their' group' (2008, p. 558). While promoting an agency-centred version of multiculturalism, she recognizes nonetheless that 'reified notions of culture are widely deployed by groups' (Squires 2008, p. 536). Phillips' approach to the intersection of individuals and groups is summarized thus by Squires (2008, p. 536): 'her primary normative concern [...] is with individuals, and the rights of individuals vis-à-vis groups; but individuals who nonetheless experience structural inequalities on the basis of group membership'. This approach draws attention to the construction of collective identities through experiences of structural inequality. In the findings reported above, some respondents attributed experiences of marginalization (i.e. threat and denigration) to their affiliation to 
the group 'Muslim', and used these to explain the need for the protection believed to be on offer in Muslim schools. In this respect, collective Muslim identity was thus in part defined by marginalized social status (which, as argued above, should be understood within broader contexts of minority/majority relations of power). Phillips's approach thus highlights that constructions of collective identity can be rooted in subjective experiences of inequality (which those affiliated with the group may deploy in their interests).

The third and 'strongest' conception of groups appears in communitarian versions of multiculturalism (Parekh 2000; Modood 2007). It emphasizes 'strong ethnic, religious or cultural identities' in order to address the circumstances facing particular groups, 'not least subjectively conceived ethno-religious minority groupings' (Meer and Modood 2009, p. 14 and 4). One danger of strong conceptualizations is that groups start to appear inflexible and homogenous. Modood (2007; 2008) answers this problem by applying Wittgenstein's idea about 'family resemblance' to groupings, and thereby suggests that groups can be coherent without the presence of definitive (essential) characteristics. The groupings are phenomenological - people are perceived (by themselves or others) as belonging to or being excluded from groups categorized by labels such as Muslim, Jewish, Sikh, etc. Underlying these labels are ideas about knowledge, practice and values, which when enacted, mark attachment and affiliation to (or exclusion from) the group. This analytical position accurately reflects certain ideas about collective identity expressed by respondents in the present study. Specifically, when respondents explained about belonging to the group Muslim, they often invoked ideas about shared knowledge, values or practice. There was, nevertheless, sometimes a blurred boundary between religion and culture, which coheres with Meer's (2008) claim that Muslim identity is a 'quasi-ethnic sociological formation'. These 'strong' conceptualizations of collective identities are thus helpful as they prioritize respondents' conceptualization of their identities, even if - analytically speaking - their outlooks may be considered essentialist.

\section{Conclusion}

In this study, advocates of Muslim schools in Britain invoked and mobilized ideas about collective Muslim identity that were based on their perception that they shared with other Muslims either knowledge values and practice and/or life experiences relating to denigrated or discordant social identities. It is not claimed, however, that these are essential characteristics of collective Muslim identity. Throughout the paper, the importance of heterogeneity and context has been reiterated. The collective Muslim identity expressed by the interviewees converged with their shared interest for a separate school provision in social conditions in which they perceived themselves to be under threat and/or attack. Theories with varying approaches to 'groups' (but all with anti-essentialist undertones) were used to understand different elements of the data: that identity constructions are context-bound processes; that subjective experience of structural inequality can inform affiliation to groups; and, that group members may experience and express their affiliations in essentialist terms. The forms of collective Muslim identity reported in this study may be thus regarded as context-dependent constructions that reflected an intersection between perceived 
An author-created final version of article published in "Ethnic and Racial Studies", 2012, 35(4): 643-663. [copyright

Taylor \& Francis], available online at: http://dx.doi.org/10.1080/01419870.2011.577899.

social conditions and interests, and which drew upon, shaped and promoted ideas about commonality and collective needs.

\section{Acknowledgements}

CT was supported by the Economic and Social Research Council (PTA-026-271361) and the Centre for Ethnicity and Citizenship, University of Bristol.

\section{References}

AHMAD, W. I. U. and VENETIA, E. 2010 'The making and representation of Muslim identity in Britain: conversations with British Muslim 'elites', Ethnic and Racial Studies, vol. 33, pp. 1697-1717

ALEXANDER, C. 1998 'Re-imagining the Muslim Community', Innovation, vol. 11, pp. $439-50$

BAUMAN, Z. 1989 Modernity and the Holocaust. Cambridge: Polity

BOLTON, P. and GILLIE, C. 2009 Faith schools: admissions and performance. London: House of Commons Standard Note, http://www.parliament.uk/commons/lib/research/briefings/snsg04405.pdf

BRITISH SOCIOLOGICAL ASSOCIATION 2002 Statement of Ethical Practice. Available at: www.britsoc.ac.uk.

CHADWICK, P. 2001 'The Anglican Perspective on Church Schools', Oxford Review of Education, vol. 27, pp. 475-487

DOOLEY, P. 1991 'Muslim Private Schools', in G. WALFORD (ED) Tradition, Change and Diversity. London: Chapman

DWYER, C. 1993 'Constructions of Muslim Identity and the contesting of power: the debate over Muslim schools in the United Kingdom', in P. JACKSON (ED) Constructions of Race, Place and Nation. London: UCL Press, pp. 143-159

DWYER, C. 1999 'Veiled Meanings: young British Muslim women and the negotiation of differences', Gender, Place and Culture, vo. 6, pp. 5-26

DWYER, C. 2000 'Negotiating Diasporic Identities: Young British South Asian Muslim Women', Women's Studies International Forum, vol. 23, pp. 475-486

GILROY, P. 2004 After Empire: Multiculture or Postcolonial Melancholia? London: Routledge

GOMM, R. 2004 Social Research Methodology. A Critical Introduction. Basingstoke: Palgrave MacMillan

HALL, S. (1992) 'The question of cultural identity', in S, HALL, HELD, D and McGREW, T. Modernity and its Futures. Cambridge: Polity, pp. 273-325

HEMPEL, L. 2004 'What's it worth to you? The questionable value of instrumentalist approaches to ethnic identification', International Journal of Comparative Sociology, vol. 45, pp. 253-275

HEWER, C. 2001 'Schools for Muslims', Oxford Review of Education, vol. 27, pp. $515-527$

HOPKINS, P. 2007 “'Blue Squares', 'Proper’ Muslims and Transnational Networks', Ethnicities, vol. 7, pp. 61-81 
An author-created final version of article published in "Ethnic and Racial Studies", 2012, 35(4): 643-663. [copyright

Taylor \& Francis], available online at: http://dx.doi.org/10.1080/01419870.2011.577899.

JACKSON, R. 2003 'Should the State Fund Faith Based Schools? A review of the arguments', British Journal of Religious Education, vol. 25, pp 89102

JENKINS, R. 2008 Social identity. London: Routledge

KAHANI-HOPKINS, V. and HOPKINS, N. 2002 ' Representing' British Muslims: the strategic dimension to identity construction', Ethnic and Racial Studies, vol. 25, pp. 288-309

KVALE, S. 1996 InterViews. London: Sage

MASON, J. 1996 Qualitative researching. London: Sage

McCREERY, E., JONES, L. and HOLMES, R. 2007 'Why do Muslim parents want Muslim schools?', Early Years. An International Journal of Research and Development, vol. 27, pp. 203-219

McLOUGHLIN, S. 1998 “'A Part of the Community'? The politics of representation and a Muslim school's application for state funding', Innovation, vol. 11, pp. 451-70

MEER, N. 2006 “"Get off your knees”. Print media public intellectuals and Muslims in Britain', Journalism Studies, vol. 7, pp. 35-59

MEER, N. 2007 'Muslim Schools in Britain: Challenging mobilisations or logical developments', Asia Pacific Journal of Education, vol. 27, pp. 5571

MEER, N. 2008 'The politics of voluntary and involuntary identities: are Muslims in Britain an ethnic, racial or religious minority?', Patterns of Prejudice, vol. 42, pp. 61-81

MEER, N. and MODOOD, M. 2009 'The Multicultural State We're In: Muslims, 'Multiculture' and the 'Civic Re-balancing' of British Multiculturalism', Political Studies, vol. 57, pp. 473-497

MILES, R. 1989 Racism. London: Routledge

MILLER, H. 2001 'Meeting the Challenge: the Jewish schooling phenomenon in the UK', Oxford Review of Education, vol. 27, pp. 501-513

MODOOD, T. 1992 'British Asian Muslims and the Rushdie affair', Political Quarterly, vol. 61, pp. 143-160

MODOOD, T. 1998 'Anti-Essentialism, Multiculturalism and the 'Recognition' of Religious Groups', The Journal of Political Philosophy, vol. 6, pp. 378-399

MODOOD, T. 2007 Multiculturalism: a civic idea. Cambridge: Polity Press

MODOOD, T. 2008 'Multiculturalism and Groups', Social and Legal Studies, vol. 17, pp. 549-553

MODOOD, T., BERTHOUD, R. and LAKEY, J. 1997 Ethnic minorities in Britain: diversity and disadvantage. The fourth national survey of ethnic minorities. London: Policy Studies Institute

MUSLIM COUNCIL OF BRITAIN 2007 Towards Greater Understanding: Meeting the needs of Muslim pupils in state schools. London: Muslim Council of Britain

PAREKH, B. 2000 Rethinking multiculturalism: cultural diversity and political theory. Basingstoke: Macmillan

PARKER-JENKINS, M. 2002 'Equal Access to State Funding: the case of Muslim schools in Britain', Race, Ethnicity and Education, vol. 5, pp 273-89

PARKER-JENKINS, M., HARTAS, D. and IRVING, B. A. 2005 In good faith: schools, religion, and public funding. Aldershot: Ashgate 
An author-created final version of article published in "Ethnic and Racial Studies", 2012, 35(4): 643-663. [copyright

Taylor \& Francis], available online at: http://dx.doi.org/10.1080/01419870.2011.577899.

PEEK, L. 2005 'Becoming Muslim: The Development of a Religious Identity', Sociology of Religion, vol. 66, pp. 215-43

PHILLIPS, A. 2007 Multiculturalism without Culture. Princeton, NJ: Princeton University Press

PHILLIPS, A. 2008 'More on Culture and Representation', Social and Legal Studies, vol. 17, pp. 555-558

POOLE, E. 2002 Reporting Islam. Media Representations of British Muslims. London: IB Taurus

RITCHIE, J., LEWIS, J and ELAM, G. 2003 'Designing and Selecting Samples', in J. RITCHIE and LEWIS, J (EDS) Qualitative Research practice. A guide for Social Science Students and Researchers. London: Sage, pp. 77-108

RUNNYMEDE TRUST 1997 Islamophobia: A Challenge For Us All. London: Runnymede Trust

SAID, E. 1978 Orientalism. London: Routledge and Kegan Paul

SAYYID, S. 2000 'Beyond Westphalia: Nations and Diasporas - the Case of the Muslim Umma', in B. HESSE (ED) Un/settled Multiculturalisms. NewYork: Zed Books, pp. 33-50

SCHWEDLER, J. 2001 'Islamic Identity: Myth, Menace, or Mobilizer?', SAIS Review, vol. XXI, pp. 1-17

SPIVAK, G. C. 1987 In Other Worlds: Essays in Cultural Politics. London: Routledge

SQUIRES, J. 2008 'Multiculturalism, Multiple Groups and Inequalities', Social and Legal Studies, vol. 17, pp. 535-542

STATHAM, P. 1999 'Political Mobilisation by Minorities in Britain: a negative feedback of 'race relations'?', Journal of Ethnic and Migration Studies vol. 25, pp. 597-626

STATHAM, P., KOOPMANS, R., GIUGNI, M. and PASSY, F. 2005 'Resilient or Adaptable Islam? Multiculturalism, Religion and Migrants' ClaimsMaking for Group Demands in Britain, the Netherlands and France', Ethnicities, vol. 5, pp. 427-59

THOMPSON, S. 2008 'Multiculturalism without Multiple Cultures?', Social and Legal Studies, vol. 17, pp. 543-547

TINKER, C. 2006 'Islamophobia, Social Cohesion and Autonomy: Challenging the arguments against state funded Muslim schools in Britain', Muslim Education Quarterly, vol. 23, pp. 4-19

TINKER, C. 2009 'Rights, social cohesion and identity: arguments for and against state-funded Muslim schools in Britain', Race, Ethnicity and Education, vol. 12, 539-553

TINKER, C. and ARMSTRONG, N. 2008 'From the Outside Looking in: How an Awareness of Difference Can Benefit the Qualitative Research Process', The Qualitative Report, vol. 13, pp. 53-60

WALFORD, G. 2001 'Funding for Religious Schools in England and the Netherlands: can the piper call the tune?', Research Papers in Education, vol. 16 , pp. $359-80$

CLAIRE TINKER is a Research Fellow in the Department of Social Sciences, Bath Spa University. 
An author-created final version of article published in "Ethnic and Racial Studies", 2012, 35(4): 643-663. [copyright Taylor \& Francis], available online at: http://dx.doi.org/10.1080/01419870.2011.577899.

ADDRESS: Newton Park Campus, Bath, BA2 9BN, UK. E-mail: clairetinker@hotmail.co.uk

ANDREW SMART is Senior Lecturer in the Department of Social Sciences, Bath Spa University.

ADDRESS: Newton Park Campus, Bath, BA2 9BN, UK. E-mail:

a.smart@bathspa.ac.uk

\footnotetext{
${ }^{1}$ Personal communication: Association of Muslim Schools (10/05/2010).

${ }^{2}$ Miles (1989, p. 42) defines racism as an ideology which portrays 'human beings, and the social relations between human beings, in a distorted or misleading manner'.

${ }^{3}$ This is not to suggest that all Muslims, or even all the respondents, share a common stance toward these conditions.
} 